This is an Accepted Manuscript of an article published by Taylor \& Francis Group in Policing and

Society on 13 Dec 2019, available online:

http://www.tandfonline.com/10.1080/10439463.2019.1696800.

\title{
Lights, camera, provocation? Exploring experiences of surveillance in the policing of Scottish football
}

\author{
Niall Hamilton-Smith, University of Stirling \\ Maureen McBride, University of Glasgow \\ Colin Atkinson, University of the West of Scotland
}

\begin{abstract}
Based primarily on research into the policing of football fans in Scotland following the implementation of the Offensive Behaviour at Football and Threatening Communications Act (Scotland) Act 2012 this paper examines the interplay of police techniques and surveillance technologies in the policing of Scottish football. There has been relatively little academic attention directed towards the Act, so the question of why and how this flagship legislation generated such intense opposition that it was repealed within six years of its introduction demands investigation. This paper explores the implementation of the Act from the perspectives of football fans, criminal justice agencies, and representatives of football clubs, with a specific focus on the impact of police surveillance practices. The research uncovered strong perceptions that such practices were considered intimidatory, which may have weakened the perceived legitimacy of the Act. This paper poses a challenge to simple readings of evidence in terms of the claimed benefits of particular forms of surveillance, arguing that the use of technologies such as powerful hand-held cameras and body worn video (BWV) has had a detrimental impact on police-fan relationships, interactions and dialogue.
\end{abstract}

\section{Intro}

In April 2018 the first piece of modern Scottish legislation solely introduced by a majority government in Edinburgh was ignominiously removed from the statute books; formally repealed only six years after its introduction. The Act in question, the Offensive Behaviour at Football and Threatening Communications (Scotland) Act 2012 (hereafter 'the Act'), attempted to more effectively target and criminalise certain behaviours at football matches - such as offensive remarks, songs, chants or gestures made by fans - that could be perceived as hateful or likely to provoke disorder by a 'reasonable' person. In particular, the Act was apparently designed to tackle offensiveness that centred on perceived religious background or affiliation associated with historical sectarian divisions in Scottish society. ${ }^{1}$

Whilst a cynical commentator could argue that the main impetus behind the Act's demise was that the loss of the Scottish Government's overall majority in May 2016 simply gave opposition parties the opportunity to defeat the presiding Government over something. However, that this 'something' proved to be an attack on the 2012 Act cannot be seen as mere co-incidence. The Act was an ideal target precisely because it had attracted a growing and vocal range of opponents. Curiously, there was a level of initial support for the underpinning aims of the Act, at least amongst some fans. In 2014 a national survey undertaken as part of our evaluation of the Act, using a sample frame of fans provided by Supporters Direct Scotland, found that over $80 \%$ of fans were opposed to people singing songs at football that made reference to people's religious background or beliefs or which alluded to political

\footnotetext{
${ }^{1}$ The political and media rhetoric around the Act focused on sectarianism; however, it is notable that the word 'sectarianism' - which has not been defined in law - does not appear in the text of the legislation. For a detailed discussion on how one might define the term see Advisory Group on Tackling Sectarianism in Scotland (2013).
} 
This is an Accepted Manuscript of an article published by Taylor \& Francis Group in Policing and Society on 13 Dec 2019, available online:

http://www.tandfonline.com/10.1080/10439463.2019.1696800.

support for terrorist causes (Hamilton-Smith et al., 2015: 38). ${ }^{2}$ By 2017, in a survey conducted by Supporters Direct Scotland using the same sample frame, ${ }^{3}$ whilst the majority of fans were still opposed to such behaviours at football, over $71 \%$ of fans opposed the Act as an instrument for achieving these aims (Supporters Direct Scotland, 2017: 5). The remarkable speed with which the Act generated such high levels of opposition demands explanation. Whilst much has been rightly made about the weak drafting of the Act and the extent to which the Act arguably merely duplicated legal remedies that were already available in Scots law (McBride, 2017: 237), less attention has been paid to how the implementation of the Act, specifically here in relation to the way in which it engendered intensified policing and surveillance practices, may have been a key factor in eroding support amongst fans. In turn this particular episode in Scotland sheds critical light on any empirical claims that specific forms of surveillance, such as CCTV or body worn video (BWV), can be reliably associated with particular effects.

\section{Football, policing and surveillance}

Football has long been associated with quite complex systems of surveillance and control. Haggerty and Ericson's notion of the surveillance assemblage (2000) has particular relevance here, with their emphasis on complex, evolving and fluid systems of surveillance and counter-surveillance. Surveillance assemblages can be constituted by a mix of private, corporate and state resources, which for football, with its mix of police, club and broader corporate/public surveillance (including via televised matches) is apt. Consistent with notions of over-lapping surveillance purposes, the football assemblage traditionally incorporates tensions between surveillance for the purposes of fan safety, surveillance for the purposes of entertainment, and surveillance for the purposes of control. However, the balance between these purposes has arguably shifted significantly over recent decades with the emergence of dominant concerns of football disorder and 'hooliganism' (Stott and Pearson, 2006).

The quintessential, dramatic figure at the centre of any historical narrative of football policing and disorder is the English 'hooligan'. The football hooligan, so imagined, is an individual intent on using the sporting event as a pretext to access opportunities for collective acts of spontaneous or organised violence against fans from other clubs (Dunning et al., 1991). Despite the association of such disorder with English football, Scottish football has a longer and more troubled history with violence and disorder that pre-dates the emergence of the English hooligan, principally, but not exclusively, through the 'Old Firm' sectarian rivalry between Rangers, a club traditionally considered to represent a staunch British, unionist and Protestant identity, and Celtic, a football club generally regarded as a key site for the expression of Irish identities in Scotland (Bradley, 1995; Flint and Powell, 2011). Such sectarian disorder, however, became over-shadowed in the 1970s and 1980s by a UK-wide pre-occupation with hooliganism (Poulton, 2005), and specifically an upsurge in hooliganism in domestic and international fixtures associated with English teams (Stott and Pearson, 2007). It was this spectre of hooliganism that arguably dominated the shaping of policy and policing responses and tactics across the UK, irrespective of differences in more local contexts (Coalter, 1985; Bebber, 2012).

\footnotetext{
${ }^{2}$ It is acknowledged here that the national 2014 Scottish Supporters Direct survey was skewed towards older, more conservative fans and under-represented younger sections of football 'fandom'.

${ }^{3}$ The 2014 survey did not measure fan support for the Act itself, largely because it was considered that levels of fan awareness of the Act's provisions and enforcement were too low at this early point to make any measurement meaningful or robust.
} 
This is an Accepted Manuscript of an article published by Taylor \& Francis Group in Policing and Society on 13 Dec 2019, available online:

http://www.tandfonline.com/10.1080/10439463.2019.1696800.

The political imperative to tackle hooliganism, stoked by suitably shrill media coverage, led to a considerable investment in police and criminal justice capacities to tackle the issue (Stott and Pearson 2007). Significantly, enhanced policing in and around football fixtures was combined with greater restrictions on alcohol consumption, and with stadia security and safety enhancements that included the rolling out of comprehensive CCTV systems, which rapidly expanded after the 1989 Hillsborough disaster. ${ }^{4}$ Such security measures were generally operated by clubs, but with direct coordination with policing operations. Perhaps more significantly, the scale of the hooligan threat was perceived to be great enough to merit the adoption of policing strategies usually associated with addressing more serious security threats; measures that included the deployment of plain clothes police officers to work semi-undercover on match days; uniformed surveillance teams who might typically work with mobile cameras; and an extensive intelligence infrastructure, with football intelligence officers allocated to particular clubs, being supported in some cases with networks of football fans operating as covert police informants. ${ }^{5}$

This escalation in conventional policing and surveillance resources was matched with a similar escalation in supporting legislation that targeted football disorder. The most radical example of this was the introduction in England and Wales in 2000 of football banning orders (Stott and Pearson, 2006). Designed as preventative measures, banning orders imposed potentially draconian sets of restrictions on fans who were considered at risk of involvement in football-related disorder. Restrictions could include bans on international travel (through the surrender of passports), requirements to report to local police stations on match days or during tournaments, and stadia bans for periods that could, typically, last for up to five years. ${ }^{6}$ Additionally, banning orders could also include restrictions on movement that could extend to bans on going near specified stadia or into nearby city centres on match days (James and Pearson, 2006; Stott and Pearson, 2006). Whilst these orders could be imposed upon conviction, they were also frequently imposed on the basis of the police following a civil application process; thereby requiring only a civil burden of proof for an application to be successful (i.e. proof that on the balance of probabilities that an individual might be at risk of involvement in football disorder). These orders may be seen as a part of wider shift towards riskfocused, preventative interventions in criminal justice (Zedner, 2009), and in their application within football have been persuasively critiqued as disproportionate and at odds with the human rights of fans (James and Pearson, 2015).

Conversely, whilst similar policing and legislative resources were available in Scotland, they were used with restraint. For instance, whilst football banning orders were introduced by the Scottish Government in 2006, in part with the intention to tackle sectarianism (Flint, 2008), they were used sparingly, with no use being made of (arguably) more draconian civil powers (Hamilton-Smith et al., 2011). The general focus of proactive policing strategies remained on violent disorder, which was

\footnotetext{
${ }^{4}$ The official report into the disaster, the Taylor Report, made a number of recommendations to improve safety in football stadia.

${ }^{5}$ The use of fans as informants is not well discussed in academic research, but has courted recent media attention in Scotland (see Evening Times, 2018). Despite a general academic neglect, this issue was discussed in interviews with police officers as part of the lead authors' research into the Act and his previous research into football banning orders, wherein officers reflected upon the value of such covert assets in football policing.

${ }^{6}$ If an individual is convicted of an offence that dos not command a custodial sentence, the maximum football banning order period is five years, though, more exceptionally, if an individual receives a custodial sentence a banning order of up to ten years can be imposed (see Crown Prosecution Service 2019).
} 
This is an Accepted Manuscript of an article published by Taylor \& Francis Group in Policing and Society on 13 Dec 2019, available online:

http://www.tandfonline.com/10.1080/10439463.2019.1696800.

largely considered present on the periphery of match days in the form of organised fights away from stadia (ibid., 2011). In this context, policing and surveillance within stadia appeared to have become increasingly light touch, with CCTV systems and private stewarding arrangements being concerned with crowd safety rather than crowd disorder (O'Neill, 2005). Aside from assisting ground staff in maintaining safety, the role of camera systems was largely twofold: providing retrospective evidence if a serious incident unfolded, but also, more commonly, being used by police to record and corroborate their actions, namely by directing the cameras to a particular location in the ground if they were intending to make an arrest or eject a fan (Norris and Armstrong, 1999). Outside the stadia surveillance was largely concentrated on 'high risk' games, involving a mix of plain clothes police 'spotters', who kept a watch out for known troublemakers (or 'risk' supporters in more contemporary police-speak ${ }^{7}$ ), and evidence-gathering teams with portable cameras who were tasked with monitoring fans. The value of cameras here was less in gathering evidence of actual offending, but in having a deterrent effect on fan behaviour (such policing teams being uniformed and especially 'overt') and in helping compile information that was useful for updating the intelligence picture (O’Neill, 2005).

One innovation in surveillance in Scotland came in the form of the move towards the adoption towards BWV technology, first introduced here by British Transport Police in 2015. The value of BWV for the police and Scottish prosecutors was seen to be not primarily along the conventional lines often found in the research literature: to bolster accountability, and/or de-escalating police-citizen interactions through moderating behaviours (Harries, 2010; Drover and Ariel 2015; Ariel 2016). Rather, BWV in Scotland was seen as useful for collecting supporting evidence. This was in cases where officers who were directly attending incidents that were in progress, used BWV not because video evidence was necessarily required to help establish guilt, but because when it came to subsequent legal proceedings being able to directly show the context of the offence was found to help secure a more appropriate sentence (Hamilton-Smith et al., 2011). In the context of football fans travelling to or from matches, being able to show the impact of that behaviour on others, which might typically play out in front of captive bystanders on public transport, was perceived as helping secure a more informed sentencing outcome. Overall, the policing of football in Scotland in the 2000s could justifiably be characterised as being relatively discrete, proportionate and light-touch (Hamilton-Smith and Hopkins, 2013). This relatively positive picture was to acquire more troubling hues following events in and around the football season of 2010/2011.

\section{The 'shame game' and the race to legislate}

In early 2011 a match between Celtic and Rangers sparked a period of heightened tension in relation to perceived sectarian behaviour following several on-field and touchline clashes between players and managerial staff. Despite of a lack of actual violence amongst fans, a moral panic ensued as the media obsessed over perceived 'fan behaviour'. This match was subsequently given the moniker of the 'shame game' and was regarded by some as representing the continued blight of sectarian division in contemporary Scotland (see Flint and Kelly, 2013). At the same time as this otherwise relatively unexceptional football match, a much more serious and on-going campaign of hate directed towards certain high-profile Catholics in Scotland - involving various acts such as online death threats and an

\footnotetext{
${ }^{7} \mathrm{~A}$ 'risk' supporter is an official UK policing term defined by the College of Policing in England and Wales as: 'a person, known or not, who can be regarded as posing a possible risk to public order or antisocial behaviour, whether planned or spontaneous, at or in connection with a football event.' (College of Policing, 2018).
} 
This is an Accepted Manuscript of an article published by Taylor \& Francis Group in Policing and Society on 13 Dec 2019, available online:

http://www.tandfonline.com/10.1080/10439463.2019.1696800.

attempt to send individuals viable letter bombs - was also the subject of intense media focus. These egregious acts of anti-Catholic and anti-Irish aggression were, in early 2011, highly unusual; sectarianism in Scotland has tended to manifest itself in a far subtler manner (see McBride, 2018a). The decision to introduce legislation solely targeting football supporters was therefore contentious given that the incidents reported took place outwith the context of football and appeared to be characterised by anti-Irish and anti-Catholic sentiment as much as by antipathy towards Celtic football club. Nonetheless, the Bill was eventually passed by the Scottish Parliament on 14th December 2011 and came into force on 1st March 2012. The Act was marked by opposition from the outset, and was the first piece of legislation to be passed in the Scottish Parliament without any cross-party support. Criticisms included that this was a knee-jerk and politically-motivated response, particularly given initial attempts by the presiding Scottish Government to pass the Bill as emergency legislation (Lavalette and Mooney, 2013).

\section{The study}

Our examination of police tactics and surveillance practices following the implementation of the Act is based on analysis of data drawn from primary research that involved two of the authors (HamiltonSmith and McBride, 2015), the doctoral research conducted by the second author (McBride, 2018b), and to a lesser extent from another earlier piece of research by the first author (Hamilton-Smith et al., 2011). The main piece of research, from which the data analysed here is primarily drawn, was an evaluation of section one of the Offensive Behaviour at Football and Threatening Communications (Scotland) Act 2012 undertaken for the Scottish Government. Section one of the Act centred on making it easier to police and prosecute individuals for offensive hate speech or related behaviour (including offensive songs and flags) at a football match. The evaluation was commissioned by the Scottish Government in late 2012 with the aim of examining the Act's introduction. The research was based on a mixed methods design, with fieldwork lasting from June 2013 through to early 2015. The fieldwork included a national survey of football fans undertaken in the summers of 2013 and 2014, circa seventeen and twenty nine months after the enactment of the Act (with 1,945 and 2,185 responses in each sweep respectively); focus groups with football fans from multiple clubs; interviews with practitioners from criminal justice agencies, including the police service, the prosecution service, and the judiciary, football club personnel and other football officials; observational research both at and around football fixtures; and, finally, secondary analysis of a range of criminal justice data sources on arrests, charges, prosecutions, and disposals related to football. Limited use is also made here of similar interview and administrative data collected as part of an earlier evaluation into the use of football banning orders in Scotland, a work commissioned by the Scottish Government in 2010 (Hamilton-Smith et al., 2011).

\section{Introducing the Act: shock and awe}

From the date of the introduction of the Act its provisions were rapidly utilised by police and prosecutors. This fast uptake should come as no surprise given the political investment in introducing the Act and the high-profile media attention that it attracted. Moreover, Scottish policymakers had, in contrast to the earlier introduction of football banning orders (Hamilton-Smith and Hopkins, 2013), come to appreciate the need for infrastructure, primarily resources and training, to support the Act's successful utilisation. This preparatory work focussed on a number of important steps:

- The extension of specialist prosecutors and appropriate police liaison arrangements to ensure that chargers were appropriately prioritised, evidenced, and supported 
This is an Accepted Manuscript of an article published by Taylor \& Francis Group in Policing and Society on 13 Dec 2019, available online:

http://www.tandfonline.com/10.1080/10439463.2019.1696800.

- The establishment of training programmes for key stakeholders, including club officials, to ensure that awareness of legislative powers, roles and responsibilities were clearly understood

- The creation of a specialist football policing unit to provide national specialist resources, expertise, and training resources to ensure that nationally, the police responded consistently and effectively.

The specialist football policing unit introduced alongside the Act was the Football Coordination Unit for Scotland (FoCUS). This new unit contained officers charged with overseeing policy and developing practice and associated training, as well as hosting an intelligence unit to consolidate and strengthen football intelligence. In undertaking its tasks FoCUS deployed surveillance equipment, including handheld cameras and BWV. ${ }^{8}$ FoCUS was introduced as police reform in Scotland was taking shape, and specifically the move towards establishing a single national police force that consolidated the preexisting structure (see Terpstra and Fyfe, 2014). FoCUS drew particularly heavily from one legacy Scottish police force for its staffing (Strathclyde Police, the largest of eight Scottish police forces preceding the formation of the national force, and the force from which the first Chief Constable of Police Scotland was selected). As a result, FoCUS become associated in the minds of many with a heavy-handed imposition of 'Strathclyde' policing methods and tactics that usurped the diverse range of pre-existing Scottish policing traditions, styles and richly varying community contexts (see Terpstra and Fyfe, 2015).

This perception was reinforced by FoCUS operationally deploying officers to what they determined were 'high risk' matches, typically with the prominent use of surveillance equipment. At the same time the Act, and its early enforcement by FoCUS, was heavily publicised in the media. Again, on the one hand this may be seen as helpful in terms of making fans aware of the new legal powers ${ }^{9}$ and the heightened risks of continuing to engage in behaviour that might be defined as offensive. On the other hand, the rapid and high-profile use of the new powers, imposed by a cadre of 'parachuted-in' national officers (rather than familiar, local officers), was perceived by many fans as aggressive and confrontational. In particular, some early high-profile arrests, where suspects were arrested retrospectively at home via police 'raids' appeared to produce a sense of unjust, persecution amongst some groups of fans. ${ }^{10}$

Being knocked at 6 o'clock in the morning to be arrested for swearing. That's what happened to me. Now, I'm sorry, but that's the things that the police are doing, arresting someone, a dawn raid at 6 o'clock, for swearing. (Football supporter, focus group)

\footnotetext{
${ }^{8}$ As of early 2019 Police Scotland's capability in relation to BWV is still uneven, with only certain police divisions having access to BWV capability. The numbers of devices also vary considerably between these divisions: ranging from single figures in Glasgow to over 300 in Aberdeen. As of June 2018 FoCUS had access to 22 BWV devices. ${ }^{9} 83 \%$ of fans surveyed as part of the section 1 evaluation were aware of the Act, (Hamilton-Smith et al., 2015: 34).

${ }^{10}$ These raids rapidly acquired the status of urban legend - accurate or otherwise - of being 'dawn' raids. Some arrests did occur in the morning. The perception of a particularly punitive approach was compounded by fact that some raids took place on Fridays, resulting in some suspects being held in custody over the weekend (Hamilton-Smith et al., 2015).
} 
This is an Accepted Manuscript of an article published by Taylor \& Francis Group in Policing and Society on 13 Dec 2019, available online:

http://www.tandfonline.com/10.1080/10439463.2019.1696800.

People talk about their doors getting crashed in. I understand that it's about shock and awe, front page of the newspapers, and making sure that people are challenged, but is it proportionate to what's trying to be achieved? (Club security manager, interview)

Thus, from the outset, the way in which enforcement was publicised and pursued, arguably did much to formulate a sense of opposition, grievance, and victimhood from the outset. Beyond official publicity, the sharing and recycling of stories via social media by fans themselves, both informally and via campaigning groups such as Fans Against Criminalisation, ${ }^{11}$ developed and sustained a powerful narrative of draconian policing and persecuted fandom.

\section{Disproportionality and the intensification of surveillance}

Section 1 of the Act introduced little that was new in terms of the legal powers available to prosecute offensive behaviour within the context of football (Law Society of Scotland, 2017); nor did the Act herald the introduction of new surveillance measures or technologies to target football fans. However, the Act facilitated a sudden step-change in the intensity and 'reach' of surveillance, and an increased willingness to use the full powers of the law to target more 'marginal' incidents of offensiveness. This was progressed through the creation of FoCUS, but also through strengthening prosecutorial expertise for identifying, handling and preparing cases charted under the Act. Judicial respondents were ready to acknowledge that in the aftermath of the Act, football fans as a group were subject to especially high levels of scrutiny and control:

There's no group of people more regulated than football fans. Can't stand up, take drink in, drink in the ground, sing certain songs, all of these people [....] are under constant surveillance and they know that, the police know who they are. (Sheriff, interview)

For some fans, and indeed for some sympathetic officials, the perceived harshness of the Act's enforcement was facilitated through the 'othering' and vilification of football fans by the media and the general population.

It was the way the media exacerbated football fans in general that led to the Act, and led to the vast majority of the population being in a position where they'd accept [it and its provisions]... because they don't. I don't think there's that much of the population going to the football anymore. So it's not going to affect them. If somebody brings an Act like that in, they're [those who do not attend football matches] just going... "oh well". (Football supporter, focus group)

This touches on a perception of some respondents that disapproval from so called 'armchair fans', those watching the games on television, who were ready to be offended with displays of genuine fandom from a distance, was providing - at the very least - tacit political support for the Act.

\section{Targeting}

A general sense of disproportionality supported more specific instances of complaint around how the Act was being implemented and enforced, but also more fundamentally framed how different

\footnotetext{
${ }^{11}$ Fans Against Criminalisation (FAC) was set up in 2011 to challenge the drafting and implementation of the $2012 \mathrm{Act}$, and continued to campaign against the legislation until its repeal in 2018.
} 
This is an Accepted Manuscript of an article published by Taylor \& Francis Group in Policing and Society on 13 Dec 2019, available online:

http://www.tandfonline.com/10.1080/10439463.2019.1696800.

surveillance measures were perceived. The main driver behind the implementation and targeting of the Act during its first year in particular was the deployment of FoCUS officers. Which games FoCUS units chose to police, and more specifically how they chose to target potential incidents of offensive behaviour, was predominantly left to their judgement and not to the judgement of local policing units or local match commanders (though local commanders could request FoCUS assistance). This implied, in effect, a marked degree of central control over how the legislation was used, which led in turn to perceptions amongst fan groups that the targeting of the Act was a highly politicised process aimed at certain groups of fans and certain forms of offensiveness.

The perception of unfair targeting extended to a sense that an excessive emphasis was placed on policing offensiveness within the stadia itself, whilst ignoring offensiveness across the wider match day 'footprint'. In particular, there were accusations that whilst offensiveness inside stadia would frequently be monitored, wide-scale incidents of offensive singing were largely left unmonitored and unchecked in the pubs and bars that book-ended the match experience. To test these assertions, we deployed fieldworkers both to undertake non-participant observations in stadia and in pubs, but also to undertake short semi-structured interviews with bar staff to elicit their accounts of compliance with the legislation. Even with limited sampling the results were (somewhat comically) emphatic:

We asked who policed the singing and the songs. The bar staff respondent replied that they ask people who are singing banned songs to leave the premises. "This is a Celtic pub, not an IRA pub" (Bar Staff). As the bar person was telling us that the singing of rebel songs was not tolerated in this pub the song which was blasting over the pub's PA was the SAM (Surface to Air Missile) Song with the chorus of 'ooh ah up the 'RA, ooh ah up the 'RA.' We went on to ask whether they thought the Act was working. "We just work to the rules". (Bar Staff)

(Field notes extract, Monday 6th October 2014)

Fieldwork on a particular match day, in a pub on the other side of the perceived sectarian divide, noted similar songs and singing (though no physical disorder). In all the pubs visited during fieldwork little evidence was recorded of formal or informal enforcement against such behaviour.

Within the stadia there were marked discrepancies in the experience of different groups of fans seated in different stadia sections. This was illustrated in this focus group exchange, involving two younger fans and an older fan sitting in what was perceived to be a more respectable section of a stadium:

Older Fan: I'm in [mentions stand at a football ground] at the halfway line and I can't remember the last time I saw a policeman in the stand.

Young Fan A: We're searched every game.

Young Fan B: When you come to [___ _ ] and you turn up [____ ] and walk up towards the [mentions stand], you'll see two police officers at every turnstile. You'll have a mounted police officer in front of them and you'll be searched by multiple stewards before you go in.

(Football supporter focus group)

12 'RA is short for IRA, the acronym for the terrorist organisation the Irish Republican Army. 
This is an Accepted Manuscript of an article published by Taylor \& Francis Group in Policing and Society on 13 Dec 2019, available online:

http://www.tandfonline.com/10.1080/10439463.2019.1696800.

Surveillance focussed on those sections of support - so called 'singing sections' characterised by more lively displays of fandom - that were often considered by some fans sitting elsewhere as central to the generation of an atmosphere on match day. Indeed, for some Scottish clubs these sections of support could be viewed as vital to their commercial success, with clubs attempting to accommodate them to increase their presence and commitment. Nevertheless, these sections were subject to increasingly intensive surveillance and heightened risk of sanction under the Act. So, a real tension emerged between policing offensive behaviour and maintaining an enjoyable, 'competitive' atmosphere.

The younger group had become disillusioned, because one minute they are getting told 'let's create a good atmosphere', and then when they do that then getting told 'you have gone too far', so they were like 'I am not going to the games any more'. (Football intelligence officer, interview)

[A] lot of young kids will only go to various clubs because they want to go to the singing sections and those sections that can appear political. It's colourful, its noisy, it looks fun, you want to go to that and it makes them want to go. If you calm that down then they won't want to go. (Football supporter, focus group)

An inherent tension here is that what constitutes an enjoyable competitive atmosphere centred not only on the quality of football on the pitch, but on songs and chants designed to antagonise or 'wind up' opposing fans. Such provocations can range from gentle humour to songs or chants that could depending on the audience - be perceived as offensive. Thus fans become subject to simultaneous but contradictory forms of surveillance, watched both for entertainment and for offence.

This intense selectivity in surveillance was ramped up further when it came to away games involving the key 'risk' teams (Rangers and Celtic), where the established logic that violent misbehaviour was always more likely from travelling fans was extended to a marked surveillance of a much broader population of fans out 'on-the-road' who were considered to be at risk of offensive behaviour:

Fan 1: There was a pre-season game, went to [mentions football match], and FoCUS had turned up before the bus had even left Glasgow. Now, how they found out we still don't know.

Fan 2: This was five in the morning... They followed us from where we left in the bus, followed us to [mentions location] and then when we go to [English city]. It [surveillance] was the whole day.

(Football supporter focus group)

I've been filmed a few times, up in [___ _ one year I was right beside them [the police]. And I hardly got to see the game, I just felt so intimidated by the police, filming me the whole time. Right in front of you, we were right down in the second row and you just felt as though they were constantly watching you. It just made me feel really uncomfortable. (Football fan, interview). 
This is an Accepted Manuscript of an article published by Taylor \& Francis Group in Policing and Society on 13 Dec 2019, available online:

http://www.tandfonline.com/10.1080/10439463.2019.1696800.

The perceived consequences of focussing surveillance on sections of the stadium where younger fan groups were located was not only generating a collective sense of grievance and unfairness, but also potentially provoking the very acts of offensive gestures, speech and song that officialdom were looking to find:

See just at that point, it is hard to say at young boys at $18,19,20$, when they see that level of over-policing, that level of intimidation, it's hard to tell them not to react to that. (Football supporter, focus group)

\section{Trawling and spear-fishing}

The use of a variety of surveillance cameras (from conventional CCTV camera systems to more recent innovations, such as long-range hand-held cameras and close-contact body worn cameras) in stadia settings was central to the enforcement tactics employed in support of the Act. At certain games teams of officers with cameras would generally direct their attentions towards sections of fans that were considered to be 'high risk'. This strategy was viewed as provocative and intimidatory by targeted fans. The strategy was also seen as prone to highly inconsistent enforcement outcomes, where fans at home matches may unfairly get away with songs and gestures en masse that might be more readily picked upon when captured amongst smaller fan groups in away sections.

And so you listen to this horrendous sectarian shit coming out, and nobody does anything about it. And then the next match... maybe Wee Joe Soap [a stooge or fall guy] who is sitting at the back makes some sort of, you know, vaguely sort of... statement that there might be sectarian, "We'll arrest him, let's go and get him, and we'll be seen to put this Act in place!" But last week you let five thousand sectarian arseholes sing and chant for ninety minutes sectarian shit and nobody does doodly squat [anything] about it. (Football supporter, focus group)

A further layer of discrepancy then arose in the determination of who, within a broader group of fans, should be subject to arrest and charge. Whilst misbehaving fans might have been more at risk of exposure and arrest at away games, even at larger home fixtures, individual arrests were made in the context of incidents where hundreds, or even thousands of fans, were actively participating in an offensive song or chant.

Somebody is going to be the fall guy for that, but one person at a time is going to be the fall guy. (Football intelligence officer, interview)

A sense of targeting on the basis of easy targets, in particular youth who were less discrete and/or more prone to getting particularly carried away, were viewed by many fans and by some police officers as being disproportionately liable to arrest and charge..$^{13}$

Cameras were seen as particularly instrumental to these dual processes of 'trawling' and 'spearfishing'. Behaviours amongst sections of fans were often left to 'play out' with arrests following the

\footnotetext{
${ }^{13}$ A perspective that was, at least superficially, supported in published official statistics, see Goulding and Cavanagh (2013) and Skivington and Mckenna (2014).
} 
This is an Accepted Manuscript of an article published by Taylor \& Francis Group in Policing and Society on 13 Dec 2019, available online:

http://www.tandfonline.com/10.1080/10439463.2019.1696800.

game once the police and prosecutors had reviewed footage and determined individuals whose behaviour were suitable to merit arrest; suitability here being defined not only on the basis of severity of behaviour but on the basis of being visible enough to support a successful prosecution.

Um and I think that, in terms of the police, I think their ability to do that, um has been bolstered by the fact that they've now got prosecutors who they can run things past on Monday morning - you know, "we had this incident, here's the CCTV footage, what do you think? Or 'here's the set of circumstances, so what do you think'?" (Prosecutor, interview)

Whilst police and prosecutors might have seen such retrospective identifications and arrests as a prudent use of resources and to maintain officer safety, and a sensible way to ensure that charges were only made where they were warranted and likely to stand up in court, fans saw these self-same strategies as underhand and driven by a logic that gave primacy to achieving results and prosecutions over actually policing behaviour in the ground as and when it occurred. The increased availability of handheld cameras with powerful zoom and microphone capabilities were seen as exacerbating the situation, as officers could be so distant from fans that individuals could have no idea that they were being monitored. This led even some police officers to question the legitimacy and fairness of this approach:

If you were sitting in a stand and I' $m$ standing [in close proximity] with a camera in your face in full uniform you know why I'm here. If I am 50 metres away and you can't see me, is it directed surveillance, even though they're in uniform? (Football intelligence officer, interview). ${ }^{14}$

\section{Surveillance: the impact on fan-police interactions}

The difficulty for police was that whilst fans baulked at the initial deployment of very bulky cameras on the touchline as intimidating and provocative (an issue that even FoCUS officers acknowledged), the advent of cameras that were simultaneously both more compact and more capable led to officers 'standing back', literally in the case of compact handheld cameras and perhaps more metaphorically in the case of BWV. Cameras became discrete to the point of invisibility, potentially engendering, in turn, a different form of distrust on the part of fans. In some senses this might legitimately be a case of 'damned if you do and damned if you don' $t$ ' in the context of surveillance technology being used to support a controversial piece of legislation. However, fan interview and focus group data would suggest that there was more to fan hostility than a simple dislike of any surveillance, big or small; rather, the context of how that surveillance use was intertwined with the broader style of policing in stadia seemed to be a key driver of disgruntlement.

Fan 3: I think the problem with the coppers is they have no leeway. They cannae make decisions themselves in the ground, they cannae say to yous two 'behave yourself, you can't sing that'

\footnotetext{
${ }^{14}$ Under the UK's Regulation of Investigatory Powers legislation, whereas routine 'observation' conducted in the course of a police patrol or during an event operation (like a football match) does not require authorisation as a form of 'directed surveillance', there is a point at which the duration and targeting of that 'observation' on any one individual, or group of individuals, might legally be viewed as a form of surveillance.
} 
This is an Accepted Manuscript of an article published by Taylor \& Francis Group in Policing and Society on 13 Dec 2019, available online:

http://www.tandfonline.com/10.1080/10439463.2019.1696800.

Interviewer: That's a good point because some fans refer back to days of a bit more discretion

Fan 4: Common sense

Interviewer: Have you noticed a change in that?

Fan 3: If you're given a camera by your boss to go and film somebody you're no' just going to keep it in your pocket, you're going to stand there and film and we think that's where the problem's coming from, they're looking for it (Football supporter focus group, quoted in Hamilton-Smith et al., 2015:63).

Respondents here picked up on a common theme of surveillance tactics leading to officers passively surveilling behaviour and failing to take action. Under previous practice, where discretion was exercised and more preventative tactics used, fans were often given verbal warnings, with associated opportunities for individuals or groups of fans to self-regulate and self-police before more formal police interventions were taken.

One interviewee compared her experiences of police at football matches in the past to changes in policing styles since the introduction of the Act:

I remember the police being alright, I remember the police being... kind of having a laugh with you and, you know, if you were out of line they told you that. You know, just either 'sober up and leave the ground' or 'stop fighting'... it didn't seem to be the underhand thing, it was very much out in the open, it was very much a relationship that the fans had with the police. (Football supporter, focus group)

The research, consistent with the work of Stott and Pearson (2007), found common reference to fans self-policing in support of formal policing aims. However, it was also apparent that the perceived unfairness of police strategies in enforcing the Act led to other groups of fans engaging in countersurveillance strategies to undermine formal policing.

We encourage younger fans to wear snoods [face-covering scarfs] ... so they don't get caught on camera singing anything cos you're going to get jailed, simple as that. (Football supporter, focus group)

This camera-driven style of surveillance was also claimed to reduce autonomy for frontline officers, who might now have to justify to senior offices any failure to act on the basis of recorded evidence. Some respondents linked these accountability pressures to the political nature of the Act and the subsequent pressures put on officers to make the Act a success.

Interviewer: Do they [the police] actually come up and talk to you at all?

Fan: They'll never come anywhere near you, they'll keep their distance and it'll be filming the whole time. But I think that pressure doesn't come from an individual or even a team basis in the police, it's coming from higher up and it's coming from government level. It's 
This is an Accepted Manuscript of an article published by Taylor \& Francis Group in Policing and Society on 13 Dec 2019, available online:

http://www.tandfonline.com/10.1080/10439463.2019.1696800.

a case of you need to do this because this is now your job to do this. We need these arrests, we need these figures... (Football supporter, focus group)

In the absence of routine contact between police and fans, the onus fell on stewards, often comparatively unqualified casual private labour used to provide security and crowd control within stadia, to directly interact with fans. Stewards had, even before the Act, taken on a more prominent role within Scottish stadia as clubs and police forces attempted to reduce policing costs (see O'Neill, 2005). As was evident in our earlier evaluation of football banning orders in Scotland (Hamilton-Smith et. al, 2011), whilst stewards may have enacted a basic role in ensuring crowd safety and order, they did not necessarily have sufficient knowledge, capacity or motivation to deal with more difficult disorder within stadia. Low-levels of disorder nevertheless had facilitated a gradual scaling down of police officers, with officers being available, often waiting 'backstage' within stadia, if stewards did need assistance dealing with a more serious incident.

With the advent of the Act however, this balance of roles between the police and stewards had, in part, shifted. With greater scope for officialdom to act on perceived offensive behaviour, and with the police often confining themselves to gathering video evidence of offensive conduct, the scope for stewards to take on a quasi-policing role had become enhanced, to the frequent concern of many fan respondents:

They are essentially the police officers within the stadia and I don't like that. In terms of someone that probably knows less about criminal law than I do, trying to decide whether I should be ejected from a stadia, sometimes physically. I don't like it. (Football supporter, focus group)

Given perceived ambiguities and variances in the understanding and targeting of the Act, the involvement of a highly mixed cadre of stewards appears to have further exacerbated a sense of grievance that the Act was being inconsistently enforced.

For some police and fan respondents alike, an over-reliance on stewards and on the use of surveillance technology pointed to a need for more active policing, with the interaction of the Act and surveillance technologies being seen as leading to a disengagement and a concomitant lessening of the ability of the police to positively shape fan behaviour.

The police have moved back and there is almost a non-engagement [...] standing away from the support, filming the supporters, there's been no challenge on the problematic supporters, their perception is that the police are away at a distance. (Club security manager, interview)

You would rather be in a uniform... rather than following them with a microphone and a camera... it seems to be a case of 'well instead of actually policing the situation we are just going to let them do what they want and then we are going to drag a couple of them out of their beds at four o'clock on a Sunday morning and drag them into court'... You are more likely to change your behaviour, change what you sing in a ground, if there are four of five police officers around about you in their full uniform than you are if there's some 
This is an Accepted Manuscript of an article published by Taylor \& Francis Group in Policing and Society on 13 Dec 2019, available online:

http://www.tandfonline.com/10.1080/10439463.2019.1696800.

wee, snivelling bastard with a camera behind you. (Football supporter focus group, quoted in Hamilton-Smith et al., 2015:57)

The logical outcome of surveillance technology here seems to have support Norris et al.'s original prediction that the trends in the use of surveillance in public order policing were liable to promote a shift from the active 'preservation of public tranquillity' towards more passive strategies based around post-event identification, analysis and prosecution (Norris et al., 1998:268)

However, and although data was limited in our research, there was also some suggestion that countersurveillance strategies by fans themselves, could also have been aggravating this stand-off, with officers wary of intervening in situations where they too were being subject to camera surveillance.

If they'd taken him out of the toilets and walked him out, and dealt with him out of there, it would have been fine. But they did it right at the bottom of almost of Exit 2 at _ and, all of a sudden, this seems to be the big thing in modern society, out come the phones and everybody's recording (Football intelligence officer, interview).

As with the recording of fans by the police, the recording of police officers by fans was considered to have aggravated this situation, ultimately leading to more confrontation rather than less, with fans in this incident ultimately attempting to 'rescue' the fan from being detained, leading in turn to a violent confrontation with police.

\section{Beyond the stadia: further surveillance strategies}

In our evaluation of section 1 of the Act we interviewed a wide range of police officers involved in the policing of football, from frontline officers involved in stadia policing, through to senior police officer undertaking the coordinating role of 'match commander,'15 as well as 'spotters' and football intelligence officers who often had more undercover roles, mixing with the crowd in plain clothes and collecting intelligence from informants. From our previous work on football banning orders, undercover and intelligence resources were purely targeted at pursuing 'hooligan' groups who were intent on organising violent confrontations with opposing fan groups. With the advent of the Act, we revisited many of these self-same officers for our evaluation of section 1 , and what rapidly became clear was the extent to which these surveillance resources had been partially re-focussed around the implementation and the enforcement of the Act. Whilst some officials were relatively sanguine about this, others felt strongly that the Act actively undermined their ability to police violence.

We have lost the upper hand when it comes to violence, and to me... whilst it's abhorrent and totally wrong for people to be singing songs to each other, the big issue for me around about football is, is safety and violence.... and I think the balance there is slightly wrong. (Club security manager, interview)

The capacity to address violence related not only to the practical diversion of resources to enforce the Act, but the extent to which that focus had soured relationships with more moderate fan groups who were being targeted for offensiveness. Conversely, more serious risk groups who were actively

\footnotetext{
${ }^{15}$ Now known in Scotland as an 'event lead coordinator'
} 
This is an Accepted Manuscript of an article published by Taylor \& Francis Group in Policing and Society on 13 Dec 2019, available online:

http://www.tandfonline.com/10.1080/10439463.2019.1696800.

involved in violence, avoided any obvious acts that might lead them to being charged with offensive behaviour under the Act.

The legislation's not impacting on them, in fact I see them as more active towards each other. That isn't impacting on them because [...names several 'ultra-style fan groups...] they're the ones that are getting themselves caught, so the older risk groups don't engage in sectarian singing because the way they see it is, 'I'm not going to get caught for that' (Football intelligence officer, interview, quoted in Hamilton-Smith et al., 2015: 65)

In terms of the surveillance resources used, whilst we found no evidence that informants were used in this area at the time of the evaluation ${ }^{16}$ other undercover strategies, including the use of plain clothes officers and the monitoring of social media accounts, were clearly being 'stretched' or redeployed to focus on identifying offensive behaviours defined under the Act. This use of relatively 'high policing' tactics and resources for addressing relatively low-level offences is marked, but perhaps not unreasonable given the emphasis on section 6 within the Act on targeting offensive comment and hate speech online, in particular within the context of fan forums. Nevertheless matters came to a particular head with accusations from Fans Against Criminalisation that possibly private social media accounts and/or telephone calls had been monitored and used to target police surveillance resources at their organised protests (leading in turn to complaints by the group to the Police Scotland, to the Police Investigations Review Committee, and subsequently to the Investigatory Powers Tribunal). ${ }^{17}$ Regardless of the substance behind their particular complaints, the utilisation of sophisticated policing resources to pursue low-level incidents of fan offensiveness starkly illustrates the extent to which a political determination to robustly enforce the Act had led to a troubling extension of surveillance tactics. It remains unclear whether this drift was consciously centrally mandated, or whether it represented - consistent with Trottier's (2017) characterisation of much police social media intelligence use - a bottom-up 'drift,' as police officers extended social media monitoring to this new area of police focus.

\section{Discussion}

With the advent of the Act in Scotland the tensions between the varying aims of policing and surveillance at football became more acute, as a previous focus on both crowd safety and on organised violence away from stadia gave way to a broader and intensified surveillance of ambiguously defined, and bitterly contested, acts of disorder and 'offensiveness' within stadia.

This re-focussing of surveillance, on the back of much media and 'armchair' hysteria on behaviour in Scottish football grounds, seemed to represent a very corporate 're-casting' of notions of risk, with risk being as much about reputational damage to Scottish football, as being about more tangible forms of crime and disorder. Correspondingly, the target was less on disorder and offensiveness in private or broader public settings (such as public bars), and more on offensiveness within particular commercialised and televised spaces (the stadia). In this new assemblage, there were apparent inequalities and perceived hypocrisy in the targeting of surveillance, with passionate fandom both

\footnotetext{
${ }^{16}$ There has subsequently been accusations, reported on in the media, that police officers have been trying to recruit younger fans to report on the activities of their fellow football fans (see The Herald, 2018).

${ }^{17}$ Outline details of these allegations can be found here: http://fansagainstcriminalisation.blogspot.com/.
} 
This is an Accepted Manuscript of an article published by Taylor \& Francis Group in Policing and Society on 13 Dec 2019, available online:

http://www.tandfonline.com/10.1080/10439463.2019.1696800.

being nurtured and commercially desired, but simultaneously also being subject to draconian and rather capricious enforcement responses. Some commentators have also argued that particular classbased prejudices have been played out in the interpretation and targeting of this Act, with working class expressions of fandom being deemed offensive by middle class viewers (Waiton, 2016). This is a view that resonates with the work of Coleman who sees public-private surveillance practices in the neoliberal city as being simultaneously pre-occupied both with the realisation of profit through the maintenance of conflict-free, sanitised civic spaces, and with highly selective dramatisations of deviant 'others':

"...whereby the camera "objectivizes" the criminal, the deviant and the wrongdoer more often than not for the titillation, fear and entertainment of the 'law abiding' audience' " (Coleman, 2004: 300-301).

The dramatic shift in the intensity and focus of surveillance was widely felt by fans to be disproportionate and unfairly selective, with surveillance concentrated on certain behaviours, amongst certain fans, in certain stadia, for certain matches. Through our evaluation there was clearly a strong sense of injustice felt amongst ordinary fans, and some anecdotal evidence that closer links were being forged between singing sections and younger fans, with long-established violent 'risk groups'. This would be consistent with work of Stott and Pearson (2007) as regards to policing football crowds, as well Reicher's influential work on the psychology of crowds more generally, and the related consequences of undifferentiated policing tactics (Reicher et al., 2004).

The implications from these parallel areas of research are that if police strategies do not adequately differentiate between ordinary fans, and groups of fans intent on real organised violence, then otherwise law-abiding fans are less likely to support and co-operate with the police, and at worst may 'converge' with some of these higher risk fan elements around a shared sense of injustice and victimhood. This convergence would appear all the more likely in circumstances where policing practices had the potential to indiscriminately catch and criminalise fans in a widening surveillance net, again resonating with the predictions of Armstrong and Norris:

"Not only, therefore, is the net widened, but the potential for deviancy amplification in public order situations is increased. And as previously marginal demonstrators are caught up in the mêlée and subsequently identified, arrested and prosecuted, their fledgling deviant identities may well become entrenched." (Norris et al., 1998: 269).

Surveillance, and in particular the re-purposing of cameras and BWV technology to focus on offensiveness, appears to have been counter-productive. Whilst our original evaluation found that surveillance in certain key stadia deterred many from participating in offensive behaviour, cameras more broadly appeared neither to 'moderate' police-fan interactions or assist police in terms of boosting their legitimacy in enforcing the Act. On the contrary, the use of handheld and BWV cameras was viewed by some fans as provocative and symptomatic of the police stepping back from actively policing fan behaviour, through dialogue, challenge and positive influence. Cameras were there not only to surveil fans, but also to surveil the police; arguably inhibiting the use of discretion and common sense by frontline officers in keeping the peace, instead requiring them merely to 'capture' behaviours that could then be subsequently sifted for prosecutable acts of offensiveness. This impassive and unyielding form of surveillance may have deterred some fans from misbehaviour, but it appears to 
This is an Accepted Manuscript of an article published by Taylor \& Francis Group in Policing and Society on 13 Dec 2019, available online:

http://www.tandfonline.com/10.1080/10439463.2019.1696800.

have clearly provoked others, possibly producing the very offensiveness that such surveillance was intended to prevent in the first place.

Recent analysis of other areas of policing in Scotland has noted similar processes. This 'coconstruction' of forms of offending between the police and the policed is 'rooted in the interplay between people, practitioners, cultures, circumstances, practices, places, organizations and the systems that underpin such encounters' (Schinkel et al., 2019). Importantly, this co-construction of offending is rooted both in developments before any encounter - including processes of intelligence briefing and risk assessment - and the nature of the interaction between the parties in the encounter itself. Under the Act we would observe a marked shift in the focus of policing manifest in both preencounter targeting and surveillance, and in the quality and 'feel' of police-fan encounters within stadia. The ineluctable qualities of this co-construction are well-suited to explain the outcomes of the intense experiences of young Scottish football fans who feel that they are targeted, intimidated and over-policed, and who thus may react accordingly.

In conclusion, it is worth reflecting on how our research findings appear to run-counter to much of the existing literature on the benefits of certain forms of surveillance. Camera technology that ordinarily may help soften police-public interactions in the context of poor existing relationships, may have had the inverse impact here in the context of relatively good pre-existing practices. In enforcing the Act, police officers, for many of our respondents, merely become distant and empty vessels for channelling the (perceived) oppressive gaze of the state. Going forward, these findings have particular relevance in Scotland given ongoing police discussion around increasing the use of BWV in frontline policing. Our findings also seem consistent with other research into Scottish policing, where attempting to improve police practices through imposing procedures that ignore the existing expertise and context-tailored approaches of frontline offices, can have surprisingly counter-intuitive and negative consequences (Macqueen and Bradford, 2017). ${ }^{18}$ Finally, this brings us, perhaps inevitably, into the orbit of Lipsky (1980) and his perennially relevant notion of street level bureaucracy; for whilst the good frontline officer may not be able to escape their obligation to uphold the powers of the state (Musheno and Maynard-Moody, 2015) they can, through the sensible use of discretion and negotiation, do much to legitimise that power and win co-operation and compliance from citizens.

\footnotetext{
18 MacQueen and Bradford attempted to replicate an Australian procedural justice experiment using a randomised control trial with Scottish traffic police officers, some of whom were given a 'script' to improve police-public encounters during traffic stops.
} 
This is an Accepted Manuscript of an article published by Taylor \& Francis Group in Policing and Society on 13 Dec 2019, available online:

http://www.tandfonline.com/10.1080/10439463.2019.1696800.

\section{References}

Advisory Group on Tackling Sectarianism in Scotland, 2013. Independent Advice to Scottish Ministers and Report on Activity 9 August 2012 - 15 November 2013. Scottish Government.

Ariel B., 2016. Increasing cooperation with the police using body worn cameras. Police Quarterly, 19 (3): 326-362.

BBC News, 2011. Parcel bombs sent to Neil Lennon, McBride and Godman. 20 April. Available at https://www.bbc.co.uk/news/uk-scotland-glasgow-west-13129139 [Accessed 8 May 2019].

Bebber, B., 2012. Violence and racism in football: politics and cultural conflict in British society, 19681998. London: Pickering \& Chatto.

Bradley, J., 1995. Ethnic and religious identity in Scotland: politics, culture and football. Aldershot: Avebury.

Coalter, F., 1985. Crowd behaviour at football matches: a study in Scotland. Leisure Studies, 4 (1): 111117.

Coleman, R., 2004. Reclaiming the Streets: Closed Circuit Television, Neoliberalism and the Mystification of Social Divisions in Liverpool, UK. Surveillance and Society, 2 (2/3): 293-309.

College of Policing, 2018. Policing football. 11 December. Available at: https://www.app.college.police.uk/app-content/public-order/policing-football [Accessed 17 April 2019].

Crown Prosecution Service, 2019. Football Related Offences and Football Banning Orders. Availabe at: https://www.cps.gov.uk/legal-guidance/football-related-offences-and-football-banningorders [Accessed 17 September 2019].

Drover, P. and Ariel B., 2015. Leading an experiment in body-worn video cameras. International Criminal Justice Review, 25 (1): 80-97.

Dunning, E., Murphy, P. and Waddington, I., 1991. Anthropological versus sociological approaches to the study of soccer hooliganism: some critical notes. Sociological Review, 39 (3): 459-478.

Evening Times, 2018. Police Scotland accused of trying to turn young football fans into paid informants. 10 September. Available at: https://www.eveningtimes.co.uk/news/16832185. policescotland-accused-of-trying-to-turn-young-football-fans-into-paid-informants [Accessed 17 April 2019].

Flint, J., 2008. Governing sectarianism in Scotland. Scottish Affairs, 63 (1): 120-137.

Flint, J. and Kelly, J., 2013. Bigotry, football and Scotland. Edinburgh: Edinburgh University Press.

Flint, J. and Powell, R., 2011. "They sing that song": sectarianism and conduct in the informalised spaces of Scottish football. In: Burdsey, D. (Ed.) Race, ethnicity and football: persistent debates and emergent issues. London: Routledge, 191-206.

Goulding, A. and Cavanagh, B., 2013. Charges reported under the Offensive Behaviour at Football and Threatening Communications (Scotland) Act (2012) in 2012-13. Edinburgh: The Scottish Government. Available at: https://www2.gov.scot/resource/0042/00425855.pdf [Accessed 17 April 2019].

Haggerty, KD. and Ericson, RV., 2000. The surveillant assemblage. British Journal of Sociology, 51 (4): 605-622.

Hamilton-Smith, N., Bradford, B., Hopkins, M., Kurland, J., Lightowler C., McArdle D., and Tilley, N., 2011. An Evaluation of Football Banning Orders in Scotland. Scottish Government. Scottish Government. Edinburgh: The Scottish Government. Available at: https://www.gov.scot/publications/evaluation-football-banning-orders-scotland/pages/0 [Accessed 17 April 2019]. 
This is an Accepted Manuscript of an article published by Taylor \& Francis Group in Policing and Society on 13 Dec 2019, available online:

http://www.tandfonline.com/10.1080/10439463.2019.1696800.

Hamilton-Smith, N. and Hopkins, M., 2013. The transfer of English legislation to the Scottish context: Lessons from the implementation of the Football Banning Order in Scotland. Criminology and Criminal Justice, 13 (3): 279-297.

Hamilton-Smith, N., Anderson, S., Simpson, I., McArdle, D., McBride, M., Goodall, K., Haynes, R., Jago, N. and Crawford, J., 2015. An evaluation of section 1 of the Offensive Behaviour at Football and Threatening Communications (Scotland) Act 2012. Edinburgh: Scottish Government. Available at: https://www.gov.scot/publications/evaluation-section-1-offensive-behaviour-footballthreatening-communications-scotland-act-2012/pages/4 [Accessed 17 April 2019].

James, M. and Pearson, G., 2006. Football banning orders: analysing their use in court. The Journal of Criminal Law, 70 (6): 509-530.

James, M. and Pearson, G., 2015. Public order and the rebalancing of football fans' rights: Legal problems with pre-emptive policing strategies and banning orders. Public Law 458-475.

Law, A., 2016. Sectarianism, criminalisation and the civilising process in Scotland. In: H. Croall, G. Mooney, and M. Munro., eds. Crime, Justice and Society in Scotland. Abingdon: Routledge, 99-114.

Law Society of Scotland, 2017. Written Evidence: Offensive Behaviour at Football and Threatening Communications (Repeal) (Scotland) Bill. 18 ${ }^{\text {th }}$ August 2017. Available at: https://www.parliament.scot/S5 JusticeCommittee/Inquiries/OBR117-LawSociety.pdf [Accessed 17 April 2019].

Lavalette, M. and Mooney, G., 2013. The Scottish state and the criminalisation of football fans. Criminal Justice Matters, 93 (1): 22-24.

Lipsky, M., 1980. Street-level bureaucracy: dilemmas of the individual in public services. New York: Russell Sage Foundation.

MacQueen, S. and Bradford, B., 2017. Where did it all go wrong? Implementation failure-and morein a field experiment of procedural justice policing. Journal of Experimental Criminology, 13 (3): 321-345.

McBride, M., 2017. The Offensive Behaviour at Football and Threatening Communications (Scotland) Act 2012 - assessing the case for repeal. Edinburgh Law Review, 21 (2): 234-239.

McBride, M., 2018a. The contemporary position of Irish Catholics in Scotland. In: N. Davidson, M. Liinpää, M. McBride, and S. Virdee, eds. No problem here: understanding racism in Scotland. Edinburgh: Luath Press, 69-89.

McBride, M., 2018b. Rethinking sectarianism: a qualitative exploration of the meanings and experiences of football supporters in the west of Scotland. Unpublished PhD Thesis. Glasgow: University of Glasgow.

Mushano, M. and Maynard-Moody, S., 2015. 'Playing the rules': discretion in social and policy context. In: P. Hupo, M. Hill, and A. Buffat, eds Understanding street-level bureaucracy. Bristol: Policy Press, 169-186.

Norris, C., Moran, J., and Armstrong, G., 1998. Surveillance, Closed Circuit Television and Social Control. Aldershot: Ashgate.

Norris, C. and and Armstrong, G., 1999. The maximum surveillance society. Oxford, UK: Berg.

O’Neill, M. (2005). Policing football: social interaction and negotiated disorder. Basingstoke: Palgrave Macmillan.

Poulton, E., 2005. English media representation of football-related disorder: brutal, short-hand and simplifying? Sport in Society, 8 (1): 27-47.

Reicher, S., Stott, C., Cronin, P. and Adang, O., 2004. An integrated approach to crowd psychology and public order policing. Policing, 27 (4): 558-572. 
This is an Accepted Manuscript of an article published by Taylor \& Francis Group in Policing and Society on 13 Dec 2019, available online:

http://www.tandfonline.com/10.1080/10439463.2019.1696800.

Schinkel, M., Atkinson, C. and Anderson, S., 2019. 'Well-kent faces': policing persistent offenders and the possibilities for desistance. The British Journal of Criminology, 59 (3): 634-652.

Skivington, K. and Mckenna, J., 2014. Charges reported under the Offensive Behaviour at Football and Threatening Communications (Scotland) Act (2012) in 2013-14. Edinburgh: The Scottish Government. Available at: https://www.webarchive.org.uk/wayback/archive/20180518121722/http://www.gov.scot/Public ations/2014/06/8566/downloads [Accessed 17 April 2019].

Stott, C. and Pearson, G., 2007. Football hooliganism: policing and the war on the English disease. London: Pennant Books.

Stott, C. and Pearson, G., 2006. Football banning orders, proportionality and public order. Howard Journal of Criminal Justice, 45 (3): 241-254.

Terpstra, J. and Fyfe, N.R., 2014. Policy processes and police reform: Examining similarities and differences between Scotland and the Netherlands. International Journal of Law, Crime and Justice, 42 (4): 366-383.

Terpstra, J. and Fyfe, N.R., 2015. Mind the implementation gap? Police reform and local policing in the Netherlands and Scotland. Criminology \& Criminal Justice, 15 (5): 527-544.

The Herald, 2018. Police Scotland accused of trying to turn young football fans into paid informants. 9 September. Available at: https://www.heraldscotland.com/news/16735745. police-scotlandaccused-of-trying-to-turn-young-football-fans-into-paid-informants [Accessed 17 April 2019].

Trottier, D ., 2017. 'Fear of contact': police surveillance through social networks. European Journal of Cultural and Political Sociology, 4 (4): 457-477.

Waiton, S., 2016. Criminalizing songs and symbols in Scottish football: how anti-sectarian legislation has created a new 'sectarian' divide in Scotland. Soccer and Society, 19 (2): 169-184.

Zedner, L., 2009. 'Fixing the future. The pre-emptive turn in criminal justice'. In: S. Bronnit, B. McSherry and A. Norrie, eds., Regulating Deviance: The redirection of criminalisation and futures of criminal law. Oxford: Hart, 35-58. 